\title{
Media Video Pembelajaran pada Muatan IPA Topik Perubahan Energi
}

\section{Ni Luh Putu Ayu Evi Handayani1*, Gede Wira Bayu², I Gusti Ayu Tri Agustiana ${ }^{3}$}

1,2,3 Program Studi Pendidikan Guru Sekolah Dasar, Universitas Pendidikan Ganesha, Singaraja, Indonesia

\section{ART ICLE INFO}

Article history:

Received Auguts 22, 2021

Revised August 30, 2021

Accepted September 14, 2021

Available online October 25, 2021

Kata Kunci:

Media Video Pembelajaran, IPA

Keywords:

Learning Video Media, Science

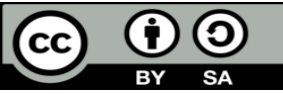

This is an open access article under the $\underline{C C}$ BY-SA license.

Copyright (C) 2021 by Author. Published by Universitas Pendidikan Ganesha.

\begin{abstract}
A B S T R A K
Partisipasi siswa dalam pembelajaran belum banyak ditemukan. Hal ini disebabkan oleh beberapa faktor. Salah satu faktor tersebut adalah masih minimnya penggunaan media pembelajaran. Penelitian ini bertujuan untuk mengembangkan media video pembelajaran pada muatan IPA topik Perubahan Energi untuk siswa kelas IV Sekolah Dasar yang valid. Pengembangan media video pembelajaran pada penelitian ini berpedoman pada prosedur ADDIE yang terdiri dari beberapa tahapan, yaitu: analisis, perancangan, pengembangan, implementasi, dan evaluasi. Namun, karena keterbatasan waktu, finansial, tenaga, dan sumber daya maka tahap implementasi tidak dilaksanakan. Subjek uji coba pada penelitian ini yaitu 2 orang ahli materi, 2 orang ahli media dan 2 orang praktisi. Pengumpulan data penelitian ini menggunakan metode kuesioner dengan memberikan lembar penilaian kepada dua orang dosen ahli media, dua orang dosen ahli materi IPA, dan dua orang guru kelas IV SD. Data hasil validasi dari para ahli kemudian dianalisis dengan menggunakan rumus mean untuk mengetahui rata-rata skor validitas media video pembelajaran IPA. Rata-rata skor validitas media video pembelajaran IPA dari segi ahli materi sebesar 4,75 dengan kualifikasi sangat baik, dari segi ahli media sebesar 4,65 dengan kualifikasi sangat baik, dan dari segi praktisi sebesar 4,5 dengan kualifikasi sangat baik. Hal ini menunjukkan bahwa media video pembelajaran pada muatan IPA topik Perubahan Energi untuk siswa kelas IV Sekolah Dasar dinyatakan layak untuk digunakan dalam proses pembelajaran.
\end{abstract}

\section{A B S T R A C T}

Student participation in learning has not been found much. This is caused by several factors. One of these factors is the lack of use of learning media. This study aims to develop a valid learning video media on the science content of the topic of Energy Change for fourth grade elementary school students. The development of learning video media in this study was guided by the ADDIE procedure which consisted of several stages, namely analysis, design, development, implementation, and evaluation. However, it is due to limited time, financial, energy, and resources, the implementation and evaluation stages were not carried out. The subject of this research were 2 materials expert, 2 media expert and 2 practitioners. This research data collection used a questionnaire method by giving assessment sheets to two media expert lecturers, two science material expert lecturers, and two fourth grade elementary school teachers. The validation data from the experts were analyzed using the mean formula to find out the validity score average of the science learning video media. The validity score average of the science learning video media in terms of material experts was 4.75 with very good qualifications, in terms of media experts was 4.65 with very good qualifications, and from the practitioner's point of view was 4.5 with very good qualifications. This showed that the learning video media on the science content of the topic of Energy Change for fourth gradeelementary school students was stated feasible to be used in the learning process.

\section{PENDAHULUAN}

Kebijakan pelaksanaan pembelajaran daring di Indonesia dimulai sejak adanya pandemi virus covid-19 yang melanda Indonesia dan beberapa negara di dunia (Abidah et al., 2020; Syah, 2020). Pembelajaran daring menjadi salah satu solusi pencegahan penyebaran virus pada bidang pendidikan(Astini, 2020; Salsabila et al., 2020; Wahyono et al., 2020). Pada umumnya kegiatan pembelajaran dilakukan proses tatap muka antara guru dan siswa, dimana guru dan siswa berada dalam satu ruangan yang sama untuk melaksanakan kegiatan pembelajaran. Hanya saja pada pembelajaran daring proses pembelajaran dilakukan menggunakan berbagai platform digital, dimana guru dan siswa dapat belajar pada tempat yang berbeda dengan waktu yang bersamaan (Pertiwi \& Sutama, 2020; Wibawa, 2021). Kegiatan belajar mengajar melalui proses daring cenderung lebih fleksibel dan mudah disesuaikan dengan situasi dan kondisi siswa. Walaupun bersifat flesibel pelaksanaan pembelajaran daring juga memperhatikan ketentuan seperti aktivitas belajar harus menciptakan pembelajaran yang bermakna bagi siswa, tidak membebani siswa, memperhatikan kondisi, pempertimbangkan fasilitas 
belajar siswa di rumah, serta mampu memberikan umpan balik pada siswa (Wahyuni, 2017; Widiyono, 2020). Kondisi pembelajaran daring sesungguhnya menuntut siswa untuk dapat belajar secara mandiri dengan memfokuskan pada kesiapan dan ketelitian siswa dalam mengolah dan menerima pembelajaran yang disajikan secara online oleh guru (Hidayat et al., 2020; Susanty, 2020). Selain menuntut kesiapan siswa, kegiatan pembelajaran daring juga menuntut kesiapan guru dan orang tua dalam memfasilitasi proses belajar siswa dari rumah (Halik \& Aini, 2020). Dalam kegiatan belajar mengajar perlu adanya motivasi siswa dalam melaksanakan proses pembelajaran agar mampu mencapai tujuan pendidikan yang ingin dicapai. Memaksimalkan proses pembelajaran daring siswa dapat dilakukan dengan penyempurnaan sarana dan prasarana belajar yang utama yaitu media pembelajaran yang kreatif dan inovatif sesuai dengan kurikulum yang ada untuk memotivasi siswa dalam belajar dan mampu meningkatkan daya serap anak terhadap materi pembelajaran (Wahyuni, 2017).

Hanya saja pada proses pelaksanaannya dilapangan proses pembelajaran daring cenderung kurang maksimal. Terdapat berbagai problematika yang dialami oleh siswa selama pelaksanaan kegiatan pembelajaran daring, seperti kurannggnya motivasi belajar, sulitnya memahami materi ajar yang diberikan oleh guru, serta rendahya hasil belajar siswa selama proses pembelajaran daring (Asmuni, 2020; Widikasih et al., 2021). Kurang maksimalnya proses pembelajaran daring di sekolah dasar cenderung disebabkan karena kurangnya kesiapan guru dan siswa dalam menerima kebijakan proses pembelajaran yang cenderung mendadak (Putra et al., 2021). Hasil observasi yang telah dilaksanakan di SD 1 Jinengdalem menunjukkan bahwa saat pembelajaran daring guru hanya memberikan tugas kepada siswa tanpa menjelaskan terlebih dahulu materi ajar sesuai topik yang dibelajarkan. Selain itu, kurangnya ketersediaan media pembelajaran yang dapat membantu siswa belajar secara mandiri juga berdampak pada pemahaman siswa yang rendah. Kurang maksimalnya proses pembelajaran daring tentu akan berdampak pada penurunan kualitas pembelajaran serta penurunan hasil belajar siswa. Upaya yang dapat dilakukan untuk mengatasi berbagai permasalahan dalam pembelajaran daring yakni dengan menciptakan proses pembelajaran yang bermakna bagi siswa melalui penggunaan media pembelajaran inovatif yang mampu meningkatkan pemahaman siswa. Media pembelajaran adalah sarana yang dapat membantu siswa dalam belajar (Ariston \& Frahasini, 2018). Media pembelajaran yang bersifat konkret akan sangat mendukung pembelajaran di rumah karena menjadikan pembelajaran menjadi menyenangkan, bermakna, dan menghindari pengunaan gadget yang berlebihan serta menarik perhatian belajar siswa (Abidah et al., 2020; Kurniawati, 2020). Media konkret adalah media asli yang dapat membantu guru dalam menyampaikan informasi kepada anak sekolah. Media pembelajaran ini dapat dimanfaatkan dalam proses pembelajaran yang akan membangkitkan minat baru, motivasi, dan memberi pengaruh kepada psikologis siswa (Busyaeri et al., 2016; Kurniawan et al., 2018).

Pemilihan media pembelajaran harus sesuai dengan kondisi dan karakteristik siswa sehingga media pembelajaran dapat dipahami oleh siswa dengan baik (Karisma et al., 2019). Salah satu media yang dapat digunakan untuk memotivasi dan meningkatkan minat siswa dalam belajar yaitu media video pembelajaran. Penggunaan media video pembelajaran dapat meningkatkan hasil belajar dan motivasi belajar peserta didik kelas. Beberapa hasil penelitian yang telah dilakukan sebelumnya menyebutkan bahwa media vidio pembelajaran sangat efektif untuk dikembangkan karena dapat membuat proses pembelajaran menjadi ebih efektif serta mampu meningkatkan hasil belajar siswa (Hastuti et al., 2020). Hasil penelitian berikutnya juga menyebutkan bahwa media vidio pembelajaran efektif dan valid digunakan dalam proses pembelajaran karena mampu memotivasi siswa dalam belajar (Pebriani, 2017). Penelitian lainnya juga mengungkapkan bahwa medai vidio pembelajaran sangat valid dan layak untuk dibelajarkan kepada siswa sekolah dasar karena memiliki tampilan yang menarik dengan memuat gambar dan suara (Kurniawan et al., 2018). Berdasarkan beberapa hasil penelitian tersebut dapat dikatakan bahwa medai vidio pembelajaran merupakan media yang efektif untuk dikembangkan dan dibelajarkan kepada siswa. Hal ini dikarenakan medai vidio pembelajaran memiliki karakteristik yang menarik dimana di dalam media tersebut dimuat gambar dan suara. Hanya saja pada penelitian sebelumnya, belum terdapat penelitian yang mengembangkan media video pembelajaran pada topik perubahan energi, oleh sebab itu penelitian ini akan mengembangkan lebih lanjut mengenai media video pembelajaran terhadap topik perubahan energi. Adapun tujuan dari penelitian ini yakni untuk untuk mengembangkan media video pembelajaran pada muatan IPA topik perubahan energi untuk siswa kelas IV sekolah dasar yang sudah teruji validitasnya.

\section{METODE}

Penelitian ini merupakan jenis penelitian pengembangan, yang dikembangkan dengan model penelitian ADDIE (Analyze, Design, Development, Implementation, Evaluation). Adapun desain pengembangan penelitian disajikan pada Gambar 1 . Tahap pertama yaitu analisis yang bertujuan untuk 
menganalisis kebutuhan meliputi analisis media, analisis karakteristik siswa, analisis materi serta analisis kompetensi dasar dan indikator yang baik. Tahap kedua yaitu tahap desain dengan melakukan perancangan media video pembelajaran sesuai dengan dengan kebutuhan siswa serta topik yang sudah dianalisis. Tahap ketiga yaitu pengembangan melalui pengembangan media video pembelajaran berupa desain media yang telah dirancang sebelumnya, penyampaian materi, gambar suara yang telah terealisasikan menjadi sebuah media pembelajaran yang akan diimplementasikan dalam proses pembelajaran. Tahap keempat dilakukan dengan menerapkan media video pembelajaran yang telah dirancang dan sudah valid serta layak digunakan dalam pembelajaran. Tahap kelima yaitu evaluasi bagian akhir yang akan memberikan sebuah hasil identifikasi dalam sebuah pembelajaran yang dilakukan dengan cara memperlihatkan media video pembelajaran yang sudah teruji dan layak digunakan.

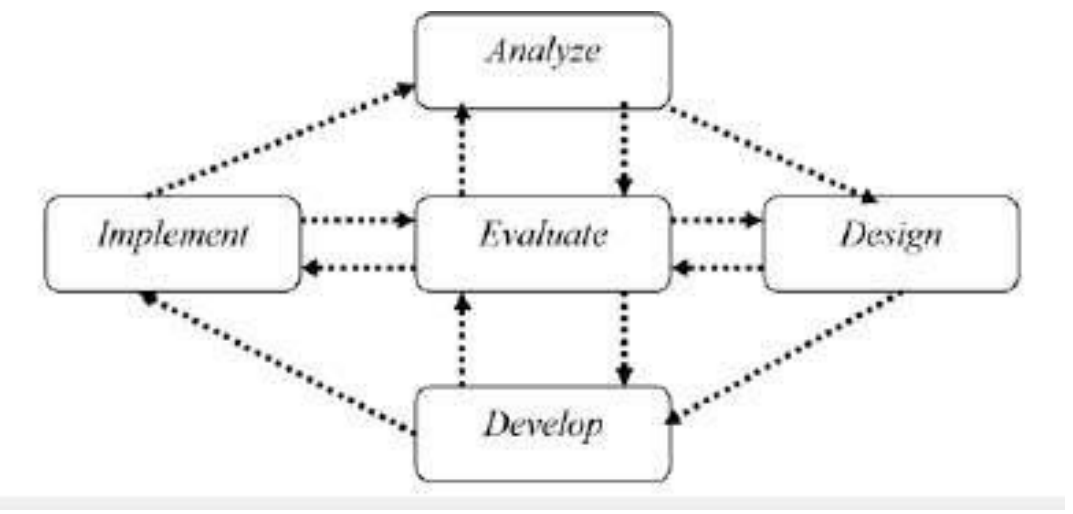

Gambar 1. Rancangan Penelitian dengan Model ADDIE (Tegeh \& Kirna, 2013)

Subjek yang terlibat pada penelitian ini yakni siswa kelas IV sekolah dasar, 2 orang ahli materi, 2 orang ahli media dan 2 orang praktisi. Pengumpulan data dalam penelitian dilakukan dengan menggunakan angket/kuisioner, wawancara dengan instrument penelitian berupa lembar validitas yang sesuai dengan kisi-kisi instrumen berdasarkan kajian pustaka. Lembar validitas kemudian dikonsultasikan dengan dosen pembimbing untuk mengumpulkan data penelitian. Instrumen penelitian digunakan untuk memperoleh data kuantitatif (angka/skor) yang kemudian dapat disajikan dalam data kualitatif. Instrument penelitian yang telah disediakan diuji validitasnya dengan menggunakan rumus Gregory. Pelaksanaan uji realibilitas dilakukan melalui penilaian 2 ahli (judges) sesuai dengan bidang yang telah diuji. Rumus yang digunakan dalam uji realibilitas ini adalah percentage of agreement. Analisis data dalam penelitian dilakukan dengan menggunakan teknik analisis data kualitatif dan analisis data kuantitatif. Analisis kualitatif pada penelitian ini bersumber dari hasil review dari para ahli berupa masukan, saran dan tanggapan terhadap media pembelajaran yang dikembangkan. Analisis deskriptif kuantitatif digunakan untuk menganalisis penilaian (angka/skor) dari hasil uji coba produk dengan menggunakan rumus mean dan percentage of agreement.

\section{HASIL DAN PEMBAHASAN}

\section{Hasil}

Pengembangan media video pembelajaran dilakukan dengan menggunakan model ADDIE yang terdiri atas 5 tahapan pengembangan yakni analyze, design, development, implementation, evaluation. Hanya saja pada penelitian pengembangan kali ini tahap implementation (implementasi) tidak dapat dilaksanakan karena adanya pandemic covid-19.Adapun hasil dari tiap tahap pengembangan media adalah sebagai berikut: tahap pengembangan yang pertama yakni tahap analyze atau analisis. Tahap analisis dilakukan menganalisis kebutuhan, karakteristik peserta didik, kurikulum, KD dan Indikator pembelajaran, serta menganalisis media. Hasil analisis kebutuhan menunjukkan bahwa perlu adanya sebuah media pembelajaran yang dapat digunakan oleh guru dalam proses pembelajaran karena terbatasnya materi dalam buku bahan ajar. Selanjutnya hasil analisis karakteristik peserta didik yaitu, diperoleh hasil bahwa anak pada tingkat sekolah dasar dinyatakan berada pada tahap operasional konkret artinya peserta didik pada tahap ini cenderung memiliki tingkat berpikir yang nyata. Analisis kurikulum dilakukan dengan analisis terhadap buku guru dan buku siswa kelas 4 Tema 2 pada muatan IPA guna memeroleh kompetensi inti dan kompetensi dasar untuk dapat mencapai tujuan pembelajaran yang ingin dicapai. Hasil analisis kurikulum yang dilaksanakan dapat dijadikan sebagai pedoman dalam 
mengembangkan media video pembelajaran. Selanjutnya pada analisis media diperoleh bahwa kriteria media yang baik dapat dilihat dari keefektifan, efisiensi, dan komunikatif.

Tahap pengembangan media yang kedua yakni tahap perancangan. Tahap perancangan dilakukan dengan menyusun instrumen penilaian media dan rancangan bangun pengembangan media video pembelajaran berbasis powerpoint. Selain itu, pada tahap ini juga dilakukan perancangan media video pembelajaran berbasis powerpoint yang dikembangkan dengan pedoman materi buku guru dan siswa kelas 4 tema 2 selalu berhemat energi. Media video pembelajaran IPA ini diperuntukan untuk siswa kelas 4 sekolah dasar. Perangkat lunak yang digunakan pada media pembelajaran ini adalah aplikasi Kinemaster untuk mengedit gambar dan video. Perancangan media ini dimulai dari merancang cover, isi materi hingga penutup melalui aplikasi Microsoft Powerpoint. Terdapat 38 slide powerpoint yang berisi materi tentang topik perubahan energi yang kemudian akan melalui tahap editing dan finishing menggunakan perangkat lunak Kinemaster. Media video pembelajaran disajikan dalam bentuk softcopy. Adapun hasil perancangan media video pembelajaran disajikan pada Gambar 2.
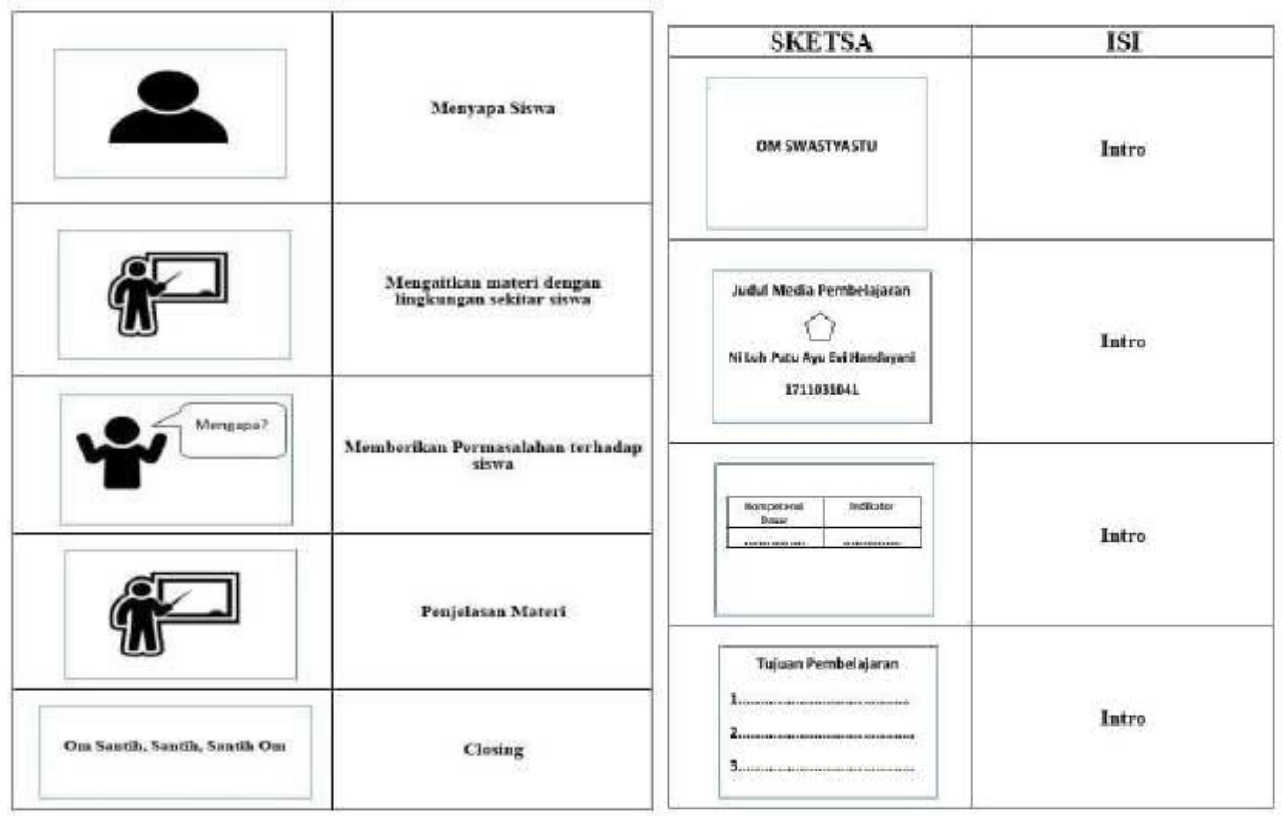

Gambar 2. Rancangan Media Video Pembelajaran IPA

Setelah tahap perancangan selesai penelitian dilanjutkan pada tahap ketiga yakni tahap pengembangan media. Pelaksanaan tahap pengembangan (development) dilakukan dengan mengembangkan produk yang sesungguhnya sesuai dengan naskah yang telah dibuat. Media video pembelajaran ini dibuat lebih menarik dengar variasi gambar animasi dan music semangat sebagai pengiringnya. Adapun hasil produk yang dikembangkan disajikan pada Gambar 3.

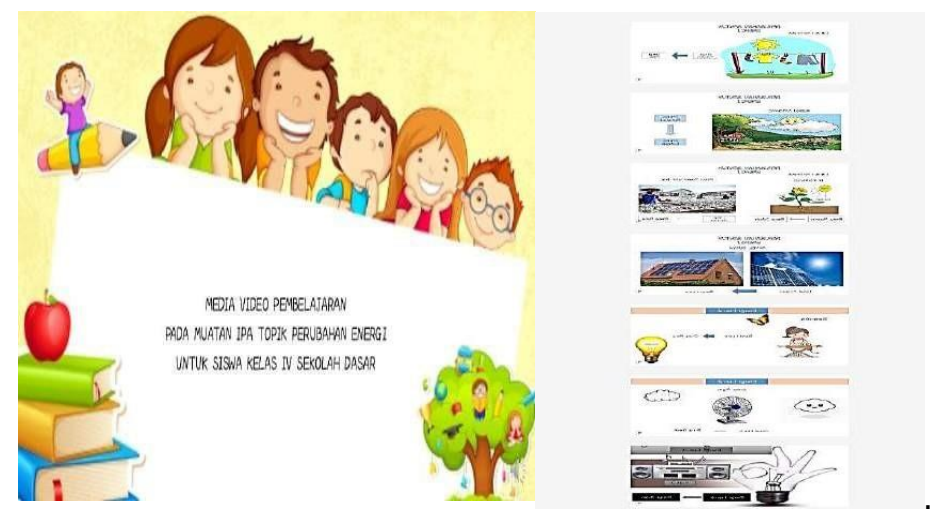

Gambar 3. Hasil Pengembangan Media Video Pembelajaran IPA

Media yang telah dikembangkan kemudian dinilai oleh para ahli dan praktisi untuk mengetahui vaiditasnya serta memeroleh saran dan komentar sehingga dapat dilakukan perbaikan terhadap media 
agar menjadi media yang layak untuk digunakan dalam proses pembelajaran. Berdasarkan hasil penilaian yang diberikan oleh ahli materi, media yang dikembangkan memeroleh nilai 4.75 dengan kualifikasi sangat baik. Hasil penilaian yang diberikan oleh ahli media, media yang dikembangkan memeroleh nilai 4,65 dengan kualifikasi sangat baik. Hasil penilaian yang diberikan oleh uji respon praktisi terhadap media yang dikembangkan memeroleh nilai 4,5 dengan kualifikasi sangat baik. Saran yang diberikan oleh para ahli untuk menyempurnakan produk media video pembelajaran IPA yang dikembangkan yaitu, pada opening media halaman judul dibuat lebih menarik, pisahkan antara judul program (media pembelajaran), tema/topik, sasaran program, dan pengembang program. Tahap pengembangan yang keempat yakni tahap evaluasi yang dilakukan dengan merevisis produk sesuai dengan saran dan masukan para ahli. Adapun hasil revisian produk disajikan pada Gambar 4.
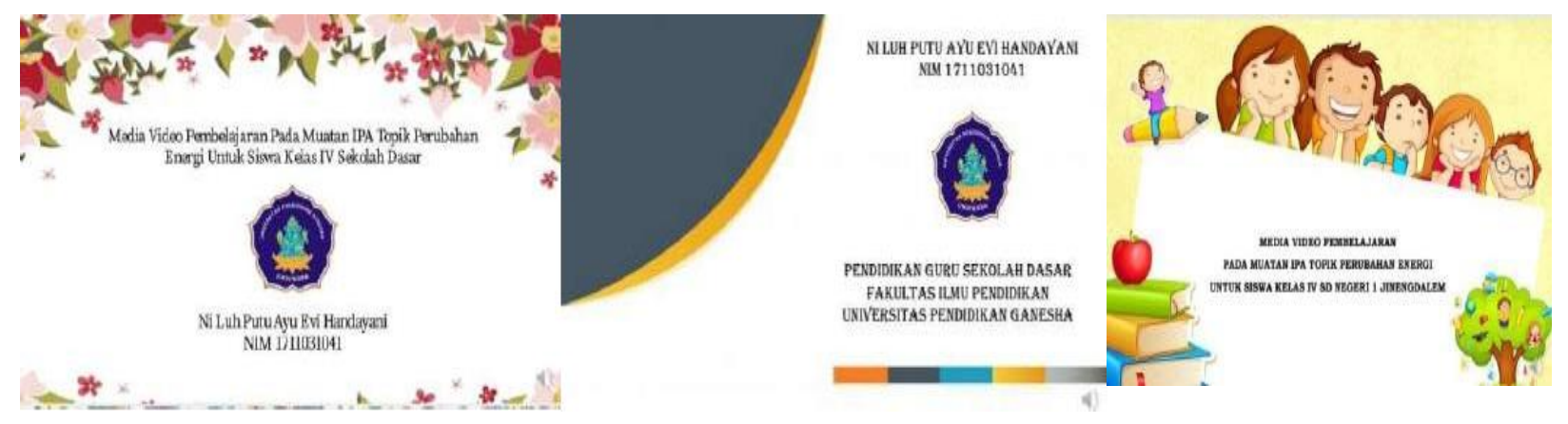

Gambar 3. Hasil Revisian Media Video Pembelajaran IPA

\section{Pembahasan}

Berdasarkan hasil analisis penelitian dan penilaian dari para ahli dan praktisi, dapat dikatakan bahwa media video pembelajaran pada muatan IPA topik perubahan energi untuk siswa kelas IV sekolah dasar yang dikembangkan telah valid dan layak untuk digunakan dalam proses pembelajaran. Media video pembelajaran IPA ini layak diterapkan dalam proses pembelajaran disebabkan oleh beberapa faktor yaitu sebagai berikut, pertama media video pembelajaran yang dikembangkan pada penelitian ini berbeda dengan media video pembelajaran yang pernah dikembangkan sebelumnya, karena belum ada video pembelajaran yang mengembangkan media video pembelajaran pada muatan IPA topik perubahan energi untuk siswa kelas IV sekolah dasar. Kedua, media video pembelajaran IPA yang dikembangkan pada penelitian ini dikembangkan dengan animasi gambar, warna, background, dan backsound yang menarik bagi siswa. Ketiga, media video pembelajaran IPA telah dikembangkan berdasarkan analisis kebutuhan, media video pembelajaran IPA pada penelitian ini dapat menjadi solusi untuk mengatasi masalah yang ditemukan dan siswa lebih mudah memahami materi pembelajaran. Selain itu, adanya pengembangan media video pembelajaran ini juga dapat membantu memudahkan guru dalam penyampaian materi pembelajaran kepada siswa khususnya pada topik perubahan energi.

Media video pembelajaran layak diterapkan dalam proses pembelajaran karena dapat merangsang kemauan siswa dalam belajar selain ini media video pembelajaran juga dapat menarik minat dan perhatian siswa. Hal ini disebabkan karena kualitas tampilan media yang sangat baik. Tampilan media yang menarik dapat meningkatkan semangat siswa dalam belajar (Busyaeri et al., 2016; Karisma et al., 2019; Pebriani, 2017). Selain itu, media ini juga menggunakan kualitas bahasa yang baik sehingga memudahkan siswa belajar. Kualitas bahasa yang baik akan membuat siswa semakin terangsang dan meningkatkan minat siswa dalam belajar (Baiduri et al., 2019; Hastuti et al., 2020; Mapicayanti et al., 2018). Kemudahan dari media video pembelajaran IPA pada topik perubahan energi ini dikembangkan agar dapat membantu siswa belajar dengan gaya belajar visual dan auditori. Gaya belajar visual adalah gaya belajar yang lebih banyak memanfaatkan indera penglihatan (Sutama et al., 2014). Gaya belajar auditorial adalah gaya belajar yang lebih banyak menggunakan atau memanfaatkan indera pendengaran sebagai penerima informasi dan pengetahuan. Penggunaan media video pembelajaran sebagai media dalam proses pembelajaran, maka akan memberikan fasilitas bagi siswa dengan gaya belajar visual dan auditori. Siswa yang belajar dengan gaya belajar visual dan auditori dapat melihat dan mendengarkan materi yang disampaikan pada video pembelajaran yang disertai dengan gambar dan warna dan penyajian materi pelajaran yang menarik sehingga siswa akan memiliki pengalaman belajar yang bermakna serta siswa akan termotivasi belajar.

Media video pembelajaran IPA ini dikembangkan dengan menggunakan model pengembangan ADDIE. Model pengembangan ADDIE dipilih karena model pengembangan ini memiliki tahapan pengembangan pembelajaran yang sistematis. Selain itu, model pengembangan ADDIE dapat digunakan 
sebagai pedoman dalam membuat dan mengembangkan media dan fasilitas program pelatihan dengan sasaran yang tepat, dinamis, dan memberikan fasilitas dalam melaksanakan (Agustien et al., 2018; Putra et al., 2014). Temuan yang diperoleh pada penelitian ini sejalan dengan temuan pada penelitian sebelumnya yang juga menyatakan bahwa media vidio pembelajaran sangat efektif untuk dikembangkan karena dapat membuat proses pembelajaran menjadi ebih efektif serta mampu meningkatkan hasil belajar siswa (Hastuti et al., 2020). Hasil penelitian berikutnya juga menyebutkan bahwa media vidio pembelajaran efektif dan valid digunakan dalam proses pembelajaran karena mampu memotivasi siswa dalam belajar (Pebriani, 2017). Penelitian lainnya juga mengungkapkan bahwa medai vidio pembelajaran sangat valid dan layak untuk dibelajarkan kepada siswa sekolah dasar karena memiliki tampilan yang menarik dengan memuat gambar dan suara (Kurniawan et al., 2018). Sehingga berdasarkan hal tersebut dapat dikatakan bahwa media video pembelajaran merupakan media yang efektif digunakan untuk membantu proses belajar siswa, kususnya di masa pandemic seperti saat ini.

\section{SIMPULAN}

Berdasarkan hasil hasil analisis data dan pembahasan dapat ditarik kesimpulan bahwa media video pembelajaran IPA yang dikembangkan mendapatkan kualifikasi sangat baik sehingga dapat dan layak digunakan dalam proses pembelajaran, serta direkomendasikan kepada guru untuk menggunakan media video pembelajaran IPA karena dapat membantu siswa dalam belajar dan lebih mudah memahami materi.

\section{DAFTAR PUSTAKA}

Abidah, A., Hidaayatullaah, H. N., Simamora, R. M., Fehabutar, D., \& Mutakinati, L. (2020). The Impact of Covid-19 to Indonesian Education and Its Relation to the Philosophy of "Merdeka Belajar." Studies in Philosophy of Science and Education, 1(1), 38-49. https://doi.org/10.46627/sipose.v1i1.9.

Agustien, R., Umamah, N., \& Sumarno, S. (2018). Pengembangan Media Pembelajaran Video Animasi Dua Dimensi Situs Pekauman di Bondowoso Dengan Model Addie Mata Pelajaran Sejarah Kelas X IPS. Jurnal Edukasi, 5(1), 19. https://doi.org/10.19184/jukasi.v5i1.8010.

Ariston, Y., \& Frahasini, F. (2018). Dampak Penggunaan Gadget Bagi Perkembangan Sosial Anak Sekolah Dasar. Journal of Educational Review and Research, 1(2), 86. https: //doi.org/10.26737/jerr.v1i2.1675.

Asmuni, A. (2020). Problematika Pembelajaran Daring di Masa Pandemi Covid-19 dan Solusi Pemecahannya. Jurnal Paedagogy, 7(4), 281-288. https://doi.org/10.33394/jp.v7i4.2941.

Astini, N. K. suni. (2020). Tantangan Dan Peluang Pemanfaatan Teknologi Informasi Dalam Pembelajaran Online Masa Covid-19. Cetta: Jurnal Ilmu Pendidikan, 3(2), 241-255. https://doi.org/10.37329/cetta.v3i2.452.

Baiduri, B. B., Taufik, M.-, \& Elfiani, L.-. (2019). Pengembangan Media Pembelajaran Pop-Up Book Berbasis Audio Pada Materi Bangun Datar Segiempat Di Smp. AKSIOMA: Jurnal Program Studi Pendidikan Matematika, 8(1), 248-261. https://doi.org/10.24127/ajpm.v8i1.1951.

Busyaeri, A., Udin, T., \& Zaenudin, A. (2016). Pengaruh Penggunaan Video Pembelajaran Terhadap Peningkatan Hasil Belajar Mapel Ipa Di Min Kroya Cirebon. Al Ibtida: Jurnal Pendidikan Guru MI, 3(1), 116-137. https://doi.org/10.24235/al.ibtida.snj.v3i1.584.

Halik, \& Aini, Z. (2020). Analisis Keaktifan Siswa dalam Proses Pembelajaran Daring di Masa Pandemi COVID-19. ENLIGHTEN (Jurnal Bimbingan Dan Konseling Islam), 3(2), 131-141. https://doi.org/10.32505/enlighten.v3i2.1887.

Hastuti, P. W., Setianingsih, W., \& Anjarsari, P. (2020). How to develop students' scientific literacy through integration of local wisdom in Yogyakarta on science learning? Journal of Physics: Conference Series, 1440(1), 0-7. https://doi.org/10.1088/1742-6596/1440/1/012108.

Hendriawan, M. A., \& Septian, A. (2019). Pengembangan JiMath Sebagai Multimedia Pembelajaran Matematika Berbasis Android Untuk Siswa Sekolah Menengah Atas. IndoMath: Indonesia Mathematics Education, 2(1), 45. https://doi.org/10.30738/indomath.v2i1.2785.

Hidayat, D. R., Rohaya, A., Nadine, F., \& Ramadhan, H. (2020). Kemandirian Belajar Peserta Didik Dalam Pembelajaran Daring Pada Masa Pandemi Covid -19. Perspektif Ilmu Pendidikan, 34(2), 147-154. https: //doi.org/10.21009/PIP.342.9.

Karisma, R., Mudzanatun, M., \& Arisyanto, P. (2019). Pengembangan Media Audio Visual untuk Mendukung Pembelajaran Tematik Tema 7 Subtema 2. Jurnal Penelitian Dan Pengembangan Pendidikan, 3(3), 216. https://doi.org/10.23887/jppp.v3i3.19255.

Kurniawan, Kuswandi, D., \& Husna, A. (2018). Pengembangan Media Video Pembelajaran Pada Mata 
Pelajaran Ipa Tentang Sifat Dan Perubahan Wujud Benda Kelas Iv Sdn Merjosari 5 Malang. JINOTEP (Jurnal Inovasi Dan Teknologi Pembelajaran) Kajian Dan Riset Dalam Teknologi Pembelajaran, 4(2), 119-125. https://doi.org/10.17977/um031v4i22018p119.

Kurniawati, D. (2020). Pengaruh Penggunaan Gadget terhadap Prestasi Siswa. Edukatif: Jurnal Ilmu Pendidikan, 2(1), 78-84. https://doi.org/10.31004/edukatif.v2i1.78.

Mapicayanti, D., Jamaludin, J., \& Fathoni, A. (2018). Perancangan Media Pembelajaran Berbasis Video Tutorial Mendesain Jaringan Lokal/LAN Kelas X TKJ. EDUMATIC: Jurnal Pendidikan Informatika, 2(2), 59. https://doi.org/10.29408/edumatic.v2i2.913.

Pebriani, C. (2017). Pengaruh penggunaan media video terhadap motivasi dan hasil belajar kognitif pembelajaran IPA kelas V. Jurnal Prima Edukasia, 5(1), 11-21. https://doi.org/10.21831/jpe.v5i1.8461.

Pertiwi, R., \& Sutama, S. (2020). Membudayakan Kelas Digital Untuk Membimbing Siswa dalam Pembelajaran di Tengah Pandemi Covid-19. JKTP: Jurnal Kajian Teknologi Pendidikan, 3(4), 350365. https://doi.org/10.17977/um038v3i42020p350.

Putra, I. G. L. A. K., Tastra, I. D. K., \& Suwatra, I. I. W. (2014). Pengembangan Media Video Pembelajaran Dengan Model Addie Pada Pembelajaran Bahasa Inggris Di SDN 1 Selat. Jurnal Edutech Universitas Pendidikan Ganesha, 2(1), 1-10. https://doi.org/10.23887/jeu.v2i1.3939.

Putra, N. P., Sudarmiani, \& Rifai. (2021). Analisis Kendala Guru dalam Pembelajaran Daring Mata Pelajaran IPS Pada Masa Pandemi COVID-19: Studi Kasus di Sekolah Menengah Pertama Kota Madiun. GEMA WIRALODRA, 12(2). https://doi.org/10.31943/gemawiralodra.v12i2.191.

Salsabila, U. H., Sari, L. I., Lathif, K. H., Lestari, A. puji, \& Ayuning, A. (2020). Peran Teknologi Dalam Pembelajaran Di Masa Pandemi Covid-19. Al-Mutharahah: Jurnal Penelitian Dan Kajian Sosial Keagamaan, 17(2), 188-198. https://doi.org/10.46781/al-mutharahah.v17i2.138.

Susanty, S. (2020). Inovasi Pembelajaran Daring Dalam Merdeka Belajar. Jurnal Ilmiah Hospitality, 9(2), 157-166. https://doi.org/10.47492/jih.v9i2.289.

Sutama, G. A., Suranata, K., \& Dharsana, K. (2014). Penerapan Teori Behavioral Dengan Teknik Modeling Untuk Meningkatkan Kemandirian Belajar Siswa Kelas AK C SMK Negeri 1 Singaraja. E-Journal Undiksa Jurusan Bimbingan Konseling, $2(1), 11$. https://www.neliti.com/id/publications/248568/penerapan-teori-behavioral-dengan-teknikmodeling-untuk-meningkatkan-kemandirian.

Syah, R. H. (2020). Dampak Covid-19 pada Pendidikan di Indonesia: Sekolah, Keterampilan, dan Proses Pembelajaran. SALAM: Jurnal Sosial Dan Budaya Syar-I, $7(5)$. https://doi.org/10.15408/sjsbs.v7i5.15314.

Tegeh, I. M., \& Kirna, I. M. (2013). Pengembangan Bahan Ajar Metode Penelitian Pendidikan dengan ADDIE Model. Jurnal IKA, 11(1), 12-26. https://doi.org/10.23887/ika.v11i1.1145.

Wahyono, P., Husamah, H., \& Budi, A. S. (2020). Guru profesional di masa pandemi COVID-19: Review implementasi, tantangan, dan solusi pembelajaran daring. Jurnal Pendidikan Profesi Guru, 1(1), 51-65. https://doi.org/https://doi.org/10.22219/jppg.v1i1.12462.

Wahyuni, Y. (2017). Identifikasi Gaya Belajar (Visual, Auditorial, Kinestetik) Mahasiswa Pendidikan Matematika Universitas Bung Hatta. Jurnal Penelitian Dan Pembelajaran Matematika, 10(2), 128132. https://doi.org/10.30870/jppm.v10i2.2037.

Wibawa, A. E. Y. (2021). Implementasi Platform Digital Sebagai Media Pembelajaran Daring Di Mi Muhammadiyah PK Kartasura Pada Masa Pandemi Covid-19. Berajah Journal, 1(2), 76-84. https://doi.org/10.47353/bj.v1i2.15.

Widikasih, P. A., Widiana, I. W., \& Margunayasa, I. G. (2021). Online Learning Problems for Elementary School Students. Jurnal of Education Reserch and Evaluation, 5(3). https://doi.org/10.23887/jere.v5i3.34254.

Widiyono, A. (2020). Efektifitas Perkuliahan Daring (Online) pada Mahasiswa PGSD di Saat Pandemi Covid 19. Jurnal Pendidikan, (2), 169-177. https://doi.org/10.36232/pendidikan. v8i2.458. 